\title{
ANALISIS STILISTIKA DALAM TUNJUK AJAR MELAYU KARYA TENAS EFFENDY
}

\author{
Sri Rahayu ${ }^{1}$, Alber $^{2}$, Hasan Basri ${ }^{3}$ \\ Universitas Islam Riau, Pekanbaru, Indonesia ${ }^{1,2,3}$ \\ srirahayu@edu.uir.ac.id ${ }^{1}$, alberuir@edu.uir.ac.id ${ }^{2}$, hasanbasri@gmail.com ${ }^{3}$
}

\begin{abstract}
Tunjuk Ajar Melayu (TAM) is very important for Malay people, especially in the past trying after all their power to disseminate, bequeath and perpetuate the teaching values referred to through literature (both oral and written). Understanding and living a literary work, one of which is through the study of stylistics. Stylistics as one of the sub-sciences in literature plays a large role in the study of literature because it examines the way the writer uses elements and language rules by looking for the effects caused by the use of language, examining the characteristics of the use of language in literature. Stylistics studied the use of the figure of speeches in its function. In this study, the researcher formulated the research problems, what was the comparative and linkage figure of speeches in TAM by Tenas Effendy?. Therefore, this research was conducted to describe, analyze, and interpret the comparative and linkage figure of speeches contained in TAM by Tenas Effendy. This research used the content analysis method. The data was collected through documentation and hermeneutic techniques. The data was documented by reading, taking notes, then summarizing and grouping according to the type of work. The results of this study were comparative figure of speeches in TAM by Tenas Effendy consisting of simile, personification, metaphor, and allegory. The linkage figure of speech in TAM by Tenas Efendy consisted of synecdoche figure of speech of tutom pro parte category.
\end{abstract}

Keyword: stylistics analysis, TAM

\begin{abstract}
ABSTRAK
Tunjuk ajar Melayu sangat penting bagi orang-orang Melayu, terutama di masa silam berusaha sehabis daya untuk menyebarluaskan, mewariskan, dan mengekalkan nilai-nilai tunjuk ajar melalui sastra (baik lisan maupun tertulis). Memahami dan menghayati sebuah karya sastra, salah satunya adalah melalui pengkajian stilistika. Stilistika sebagai salah satu subilmu dalam kesusastraan, banyak berperan dalam pengkajian sastra karena stilistika mengkaji cara sang sastrawan memanfaatkan unsur dan kaidah-kaidah kebahasaan dengan mencari efek-efek yang ditimbulkan oleh penggunaan bahasa, meneliti ciri khas penggunaan bahasa dalam sastra. Dalam stilistika dipelajari pengggunaan majas dalam penyampaiaannya. Pada penelitian ini, peneliti merumuskan masalah penelitian, apasajakah majas perbandingan dan majas pertautan yang terdapat dalam tunjuk ajar Melayu karya Tenas Effendy?. Oleh karena itu, penelitian ini dilakukan dengan tujuan mendeskripsikan, menganalisis dan menginterpretasi majas perbandingan dan pertautan yang terdapat dalam tunjuk ajar Melayu karya Tenas Effendy. Penelitian ini menggunggunakan metode content analysis. Teknik pengumpulan data menggunakan teknik dokumentasi dan hermeneutik. Data yang diteliti didokumentasi dengan cara membaca, mencatat selanjutnya disimpulkan dan dikelompokkan berdasarkan jenis majas. Hasil penelitian ini terdapat majas perbandingan dalam tunjuk ajar Melayu karya Tenas Effendy terdiri atas, majas simile, personifikasi, metafora, dan alegori. Majas pertautan dalam tunjuk ajar Melayu karya Tenas Effendy terdiri atas, majas sinekdoki kategori tutom pro parte.
\end{abstract}

Kata Kunci: analisis stilistika, tunjuk ajar Melayu

Analisis Stilistika dalam Tunjuk Ajar Melayu karya Tenas Effendy 


\section{PENDAHULUAN}

Tunjuk ajar Melayu mengandung berbagai nilai luhur yang dapat dijadikan pedoman dan bakalan hidup, yang sarat dengan nilai-nilai luhur agama dan budaya yang islami. Nilai-nilai inilah yang apabila dicerna dan dihayati, serta diamalkan dengan bersungguh hati, akan menjadi jati diri kemelayuannya. Dengan berpegang teguh kepada jatidiri itu pula setiap insan akan menjadi orang yakni menjadi manusia yang terpuji, handal, terbilang, piawai, arif dan bijaksana, berilmu pengetahuan, berwawasan luas, berbudi mulia, memiliki harkat dan martabat, tuah dan marwah, yang insya-Allah mendatangkan kesejahteraaan lahiriah dan batiniah dalam kehidupan berumah tangga, bermasyarakat, berbangsa dan bernegara (Effendy, 20131-2).

Berdasarkan pernyataan Effendy tersebut, jelas tunjuk ajar memiliki peran penting dalam kehidupan orang Melayu. Salah satu tunjuk ajar Melayu direalisasikan dalam bentuk syair. Menurut Sunarjo dalam Andriani, 2015:27) syair adalah puisi lama yang terdiri atas 4 (empat) baris yang berakhir dengan bunyi yang sama (berirama a-a-a-a). Pada umumnya syair merupakan kisah yang panjang. Semua baris merupakan isi dan biasanya tidak selesai dalam satu bait karena digunakan untik bercerita. Sementara itu, (Effendy, 2013:73) mengatakan bahwa syair mengandung isi yang beragam, terutama berupa kisah-kisah yang sarat akan makna, juga mengandung beragam petuah amanah yang lazim disebut tunjuk ajar.

Karena pentingnya tunjuk ajar Melayu dalam syair, maka orang-orang Melayu terutama di masa silam berusaha sehabis daya untuk menyebarluaskan, mewariskan dan mengekalkan nilai-nilai tunjuk ajar dimaksud melalui sastra (baik lisan maupun tertulis). Memahami dan menghayati sebuah karya sastra, salah satunya adalah melalui pengkajian stilistika. Stilistika sebagai salah satu sub ilmu dalam kesusastraan, banyak berperan dalam pengkajian sastra karena stilistika mengkaji cara sang sastrawan memanfaatkan unsur dan kaidah-kaidah kebahasaan dengan mencari efek-efek yang ditimbulkan oleh penggunaan bahasa, meneliti ciri khas penggunaan bahasa dalam sastra.

Stilistika mencakup majas, pola-pola bunyi ujaran, tipe-tipe struktur kalimat, pilihan kata atau diksi, penggunaan bahasa kiasan dan perumpamaan (Ratna, 2009:22; Fransori, 2017:3; Sudjiman dalam Munir, 2013:2; Fatmalinda dkk, 2016:993; dan Azizah dan Setiana, 2019:2). Bahasa yang digunakan dalam tunjuk ajar mengandung unsur stilistika mencakup pilihan kata dan pemajasan yang sangat bervariasi.

Selanjutnya, Nurgiyantoro (2014:215) menjelaskan pemajasan atau gaya bahasa adalah istilah lain dari bahasa figurative atau gaya pengarang mengungkapkan pikiran atau perasaannnya. Pendapat tersebut senada dengan pendapat (Keraf dalam Rosmini dkk, 2017:93; Ardin dkk, 2020:51; dan Keraf dalam Wirasari, 2018:4).

Menurut Nurgiyantoro (2014:218-244)

majas terdiri atas beberapa kategori di antaranya:

1. Majas Perbandingan Terdiri atas empat majas yaitu:

a. Simile adalah sebuah majas yang mempergunakan kata-kata perbandingan langsung atau eksplisit untuk membandingkan sesuatu yang dibandingkan dengan pembandingnya. Contoh : bagaikan banjir gulungmenggemulung, bagaikan topan seruh menderuh.

b. Metafora adalah bentuk pembandingan antara dua hal yang dapat berwujud benda, fisik, ide, sifat, atau perbuatan dengan benda, fisik, ide, sifat, atau perbuatan lain yang bersifat implisit. Contoh : ..Kaulah kandil kemerlap Pelita jendela di malam gelap Melambai pulang perlahan Sabar, setia selalu.

c. Personifikasi adalah bentuk pemajasan yang memberi sifat-sifat kemanusiaan. Artinya, sifat yang diberikan itu sebenarnya hanya dimiliki oleh manusia dan tidak untuk benda- benda atau makhluk nonhuman yang tidak bernyawa dan tidak berakal. Contoh: Jari-jari dalam diri bagai akar yang tak

Analisis Stilistika dalam Tunjuk Ajar Melayu karya Tenas Effendy 
pernah berhenti menggali bumi, makin dalam makin dalam makin kelam.

d. Alegori masih termasuk ke dalam majas perbandingan. Ada kesamaan karakteistik antara majas metafora dan majas alegori, yaitu adanya unsur yang dibandingkan itu bisa terdapat pada hal atau sesuatu yang diekpresikan dalam larik-larik tertentu. Contoh: Dalam kebun di tanah airku,Tumbuhsekuntum bunga teratai, Tersembunyi kembang indah permai,Tidak terlihat orang yang lalu.

\section{Majas Pertautan}

a. Metonimi adalah sebuah ungkapan yang menungjukkan adanya pertautan atau pertalian yang dekat antara katakata yang disebut dan makna yang sesungguhnya.

b. Sinekdoki adalah sebuah ungkapan dengan cara menyebut bagian tertentu yang penting dari sesuatu itu sendiri. Di dalam majas sinekdoki itu sendiri terdapat dua kategori penyebutan yang berkebalikan. Yang pertama, pernyataan yang hanya menyebut sebagian atau bagian tertentu dari sesuatu, tetapi itu dimaksudkan untuk menyatakan keseluruhan sesuatu, dan majas itu disebut pars pro toto. Yang kedua, penyebutan kebalikannya, yaitu pernyataan yang menyebut sesuatu secara keseluruhan, yaitu pernyataan yang menyebutkan sesuatu secara keseluruhan, namun sebenarnya itu untuk sebagian dari sesuatu tersebut, dan majas ini dikenal dengan nama totum pro parte.

Sementara itu, pilihan kata atau diksi jauh lebih luas dari apa yang dipantulkan oleh hubungan kata-kata itu. Istilah ini bukan saja dipergunakan untuk menyatakan katakata mana yang dipakai untuk menggungkapkan suatu ide atau gagasan, tetapi juga fraseologi, gaya bahasa, dan ungkapan (Keraf, 2010:22). Selanjutnya, Santoso dalam Assadiyah dkk, 2018:18) menagatakan diksi adalah pilihan kata yang tepat dan selaras untuk mengungkapkan suatu gagasan sehingga gagasan itu dapat diterima oleh pendengar atau pembaca dengan tepat. Pemilihan kata- kata yang layak atau pantas penting sekali dalam semua bentuk komunikasi, terutama dalam bahasa tulis yang harus membawakan ide atau gagasan dan sikap tanpa peragaan, ekspresi, intonasi, atau isyarat berupa gerakan tubuh.

Penggunaan majas dan diksi pada tunjuk ajar Melayu karya Tenas Effendy banyak ditemukan, sepertinya contoh di bawah ini:

Bila tunjuk ajar sengaja ditinggalkan Hiduppun jadi kehilangan pedoman Bagaikan kapal tak tentu haluan Bagaikan berjalan tak tahu tujuan Akhirnya sesat di tengah jalan

Berdasarkan contoh tunjuk ajar di atas, pada baris tiga dan empat merupakan majas simile. Penggunaan majas simile pada baris tiga dan empat tunjuk ajar tersebut ditandai dengan penggunaan kata pembanding yaitu bagaikan. Kata bagaikan merupakan kata tugas yang berfungsi sebagai penanda keeksplisitan pembandingan, terdapat pada baris Bagaikan kapal tak tentu haluan, Bagaikan berjalan tak tahu tujuan. Penggunaan majas simile pada tunjuk ajar Melayu tersebut hendaklah disimak, dihayati, dan dikekalkan melalui berbagai cara agar tidak membawa malapetaka dalam kehidupan.

Berdasarkan fenomena tersebut, peneliti tertarik melakukan penelitian dengan judul "Analisis Stilistika dalam Tunjuk Ajar Melayu Karya Tenas Effendy"

\section{METODOLOGI PENELITIAN}

Penelitain ini mengguanakan metode content analysis. Menurut Krippendorff dalam Alber (2017:39) metode analisis isi merupakan metode yang digunakan untuk mengungkapkan studi-studi terng pers dalam skala besar, penelitian sosiologis dan linguistik, terutama media mutakhir. Penelitaian analisis isi secara mendasar berorientasi empiris, bersifat menjelaskan, berkaitan dengan gejala-gejala nyata dan bertujuan predikatif. 
Teknik pengumpulan data yang digunakan dalam penelitian ini, menggunakan teknik dokumentasi dan hermeneutik, teknik ini merupakan teknik baca, catat, dan simpulkan. Teknik ini biasanya mempelajari naskah, maupun kajian sastra yang menelaah sastra yang menelaah roman, novel, dan cerpen (Hamidy, 2003:24).

1) Teknik dokumentasi yaitu buku tunjuk ajar Melayu karya Tenas Effndy.

2) Teknik baca adalah teknik yang dilakukan dengan membaca dalam buku tunjuk ajar Melayu karya Tenas Effndy.

3) Teknik catat adalah teknik yang dilakukan dengan mencatat kutipan yang terindikasi majas dalam buku tunjuk ajar Melayu karya Tenas Effndy.

4) Simpulan yaitu menyimpulkan hasil analisis data majas dalam buku tunjuk ajar Melayu karya Tenas Effndy.

\section{HASIL DAN PEMBAHASAN}

Berdasarkan deskripsi data yang dilakukan oleh penelti tentang analisis stilistika dalam tunjuk ajar melayu karya Tenas Effendy ditinjau dari penggunaan majas perbandingan dan majas pertautan sebagai berikut.

\section{Majas Perbandingan dalam Tunjuk Ajar Melayu Karya Tenas Effendy}

Kutipan 1

Wahai ananda permata ibu

Kepada Allah kita bertumpu

Semoga iman melekat dalam kalbu

Di jalan yang lurus kita menuju

Kutipan 1 larik 1 tunjuk ajar Melayu tersebut menunjukkan bahwa termasuk majas metafora dan juga majas alegori. Majas metafora adalah bentuk pembandingan antara dua hal yang dapat berwujud benda, fisik, ide, sifat ataupun perbuatan dengan benda atau benda lain yang bersifat yang bersifat implisit yang terdapat dalam baris atau larik-larik tertentu. larik 1 wahai ananda permata ibu, kata ananda yang disamakan dengan permata walau keduanya berbeda. Akan tetapi, dimaksudkan untuk menggambarkan betapa sayang atau dicintainya seoarang anak oleh ibunya. Jadi, pembandingan tersebut untuk menekankan penuturan. Kata yang bandingkan wujud benda ananda dengan wujud benda permata.

Kutipan 1 atau teks 1 juga termasuk majas alegori karena membandingkan secara keseluruhan makna teks yang bersangkutan, karena kata permata merupakan simbol seseoarang yang sangat berharga, dikasihi, dan disayangi. Kutipan tersebut diperuntukkan khusus untuk seoarng anak yang disimbolkan dengan sebuah permata. Oleh karena itu, seorang anak yang dikasihi, disayangi, dan dicintai bagaikan permata, intan, ataupun berlian bagi seorang ibu. Kutipan tersebut termasuk alegori karena majas alegoris juga dapat diungkapkan lewat metafora yang membandingkan sesuatu, dapat berupa karakter, semangat, aktivitas, bahkan juga tokoh, dengan cerita lain yang dikembangkan sebagai pembanding. Akan tetapi, membandingkan secara keseluruhan makna teks yang bersangkutan.

Kutipan 2

Wahai ananda buah hati ayah

Banyaklah sujud meyembah Allah

Mohon ampu beserta hidayah

Hidup dan matimu iman tak goyah

Kutipan 2 larik 1 tunjuk ajar Melayu tersebut menunjukkan bahwa termasuk majas metafora dan juga majas alegori. Majas metafora adalah bentuk pembandingan antara dua hal yang dapat berwujud benda, fisik, ide, sifat ataupun perbuatan dengan benda atau benda lain yang bersifat yang bersifat implisit yang terdapat dalam baris atau larik-larik tertentu. larik 1 wahai ananda buah hati ayah, kata ananda yang disamakan dengan buah hati walau keduanya berbeda. Akan tetapi, dimaksudkan untuk menggambarkan betapa sayang atau dicintainya seoarang anak oleh ayahnya. Jadi, pembandingan tersebut untuk menekankan penuturan. Kata yang bandingkan wujud benda ananda dengan wujud benda buah hati.

Kutipan 2 atau teks 2 juga termasuk majas alegori karena membandingkan secara keseluruhan makna teks yang bersangkutan, karena frasa buah hati merupakan simbol jantung hati, kekasih tercinta. Kutipan tersebut

Analisis Stilistika dalam Tunjuk Ajar Melayu karya Tenas Effendy 
diperuntukkan khusus untuk seoarng anak yang disimbolkan dengan buah hati. Oleh karena itu, seorang anak yang dikasihi, disayangi, dan dicintai dan dianggap sebagai buah hati seoarng ayah. Kutipan tersebut termasuk alegori karena majas alegoris juga dapat diungkapkan lewat metafora yang membandingkan sesuatu, dapat berupa karakter, semangat, aktivitas, bahkan juga tokoh, dengan cerita lain yang dikembangkan sebagai pembanding. Akan tetapi, membandingkan secara keseluruhan makna teks yang bersangkutan.

\section{Kutipan 3}

Wahai ananda cahaya mata

Peganglah pesan ibu dan bapa

Kepada Allah tempat meminta

Supaya hidupmu tidak bernista

Kutipan 3 larik 1 tunjuk ajar Melayu tersebut menunjukkan bahwa termasuk majas metafora dan juga majas alegori. Majas metafora adalah bentuk pembandingan antara dua hal yang dapat berwujud benda, fisik, ide, sifat ataupun perbuatan dengan benda atau benda lain yang bersifat yang bersifat implisit yang terdapat dalam baris atau larik-larik tertentu. larik 1 wahai ananda cahaya mata, kata ananda yang disamakan dengan cahaya mata walau keduanya berbeda. Akan tetapi, dimaksudkan untuk menggambarkan betapa seoarang anak dikasihi dan dijadikan pelita hati oleh kedua orang tuanya. Jadi, pembandingan tersebut untuk menekankan penuturan. Kata yang bandingkan wujud benda ananda dengan wujud benda cahaya mata.

Kutipan 3 atau teks 3 juga termasuk majas alegori karena membandingkan secara keseluruhan makna teks yang bersangkutan, karena frasa cahaya mata merupakan simbol sinar mata, kekasih tercinta, pelita hati. Kutipan tersebut diperuntukkan khusus untuk seoarng anak yang disimbolkan dengan cahaya mata. Oleh karena itu, seorang anak yang dikasihi, disayangi, dan dicintai dan dianggap sebagai cahaya mata orang tuanya. Kutipan tersebut termasuk alegori karena majas alegoris juga dapat diungkapkan lewat metafora yang membandingkan sesuatu, dapat berupa karakter, semangat, aktivitas, bahkan juga tokoh, dengan cerita lain yang dikembangkan sebagai pembanding. Akan tetapi, membandingkan secara keseluruhan makna teks yang bersangkutan.

Kutipan 4

Kepada ibu bapa ananda mengabdi

Sebagai tanda membalas budi

Lakukan dengan seikhlas hati

Supaya hidup Allah rahmati

Kutipan 4 larik 2 tunjuk ajar Melayu tersebut termasuk majas simile karena mempergunakan kata-kata perbandingan langsung atau eksplisit untuk membandingkan sesuatu yang dibandingkan dengan pembandingnya. Kata perbandingan langsung tersebut terdapat pada larik 2 sebagai tanda membalas budi yaitu penggunaan kata sebagai.

Kutipan 5

Jasa ibu bapa teramat banyak

Takkan terbayar dengan emas perak

Karenanya jangan ananda mengelak

Untuk memelihara ibu dan bapak

Kutipan 5 larik 1 dan 2 tunjuk ajar Melayu tersebut termasuk majas metafora dan juga majas alegori. Majas metafora adalah bentuk pembandingan antara dua hal yang dapat berwujud benda, fisik, ide, sifat ataupun perbuatan dengan benda atau benda lain yang bersifat yang bersifat implisit yang terdapat dalam baris atau larik-larik tertentu. larik 1 dan 2 jasa ibu bapa teramat banyak, takkan terbayar dengan emas perak. Frasa jasa ibu yang disamakan dengan emas perak walau keduanya berbeda. Akan tetapi, dimaksudkan untuk menggambarkan betapa seoarang ibu sangat berjasa dalam membesarkan anak-anak mereka. Jadi, pembandingan tersebut untuk menekankan penuturan. Frasa yang bandingkan wujud benda jasa ibu dengan wujud benda emas perak.

Kutipan 5 atau teks 5 juga termasuk majas alegori karena membandingkan secara keseluruhan makna teks yang bersangkutan, karena frasa emas perak merupakan simbol

Analisis Stilistika dalam Tunjuk Ajar Melayu karya Tenas Effendy 
perhiasan yang harus dijaga dan dipelihara dengan baik. Kutipan tersebut diperuntukkan khusus untuk seoarng ibu dan bapak yang disimbolkan dengan emas perak. Oleh karena itu, seorang anak harus menjaga dan memelihara ibu dan bapaknya dengan baik serta berbakti kepadanya. Kutipan tersebut termasuk alegori karena majas alegoris juga dapat diungkapkan lewat metafora yang membandingkan sesuatu, dapat berupa karakter, semangat, aktivitas, bahkan juga tokoh, dengan cerita lain yang dikembangkan sebagai pembanding. Akan tetapi, membandingkan secara keseluruhan makna teks yang bersangkutan.

\section{Kutipan 6}

Jasa sang guru teramatlah besar

Mereka mendidik serta mengajar

Memberi ilmu dijalan yang benar

Bagaikan cahaya di mercu suar

Kutipan 6 larik 4 tunjuk ajar Melayu tersebut termasuk majas simile karena mempergunakan kata-kata perbandingan langsung atau eksplisit untuk membandingkan sesuatu yang dibandingkan dengan pembandingnya. Kata perbandingan langsung tersebut terdapat pada larik 4 bagaikan cahaya di mercu suar yaitu penggunaan kata bagaikan.

\section{Kutipan 7}

Apabila sudah mengikat sumpah Jangan dilanggar pantang dilapah

Sumpahpun jangan diubah-ubah

Supaya hidupmu tak dimakan sumpah

Kutipan 7 larik 4 tunjuk ajar Melayu tersebut termasuk majas personifikasi karena memberikan sifat-sifat benda mati dengan sifat kemanusian. Artinya sifat yang diberikan itu sebenarnya hanya dimiliki oleh manusia dan tidak untuk benda-benda nonhuman yang tidak bernyawa dan tidak berakal. Majas tersbut terdapat pada larik 4 supaya hidupmu tak dimakan sumpah yang bermakna seolah-olah sumpah bisa makan seperti manusia. Kutipan 8

Apabila aib malu sudah tersingkap

Dunia yang terang terasa gelap

Tuah jatuh marwah pun lesap
Hidupmu hampa menjadi asap

Kutipan 8 larik 4 tunjuk ajar Melayu tersebut termasuk majas metafora dan juga majas alegori. Majas metafora adalah bentuk pembandingan antara dua hal yang dapat berwujud benda, fisik, ide, sifat ataupun perbuatan dengan benda atau benda lain yang bersifat yang bersifat implisit yang terdapat dalam baris atau larik-larik tertentu. larik 4 Hidupmu hampa menjadi asap. Kata hidup yang disamakan dengan asap walau keduanya berbeda. Akan tetapi, dimaksudkan untuk menggambarkan agar manusia bisa menjaga aib selama didunia. Jadi, pembandingan tersebut untuk menekankan penuturan. Kata yang bandingkan wujud perbuatan atau aktivitas hidup dengan wujud benda asap.

Kutipan 8 atau teks 8 juga termasuk majas alegori karena membandingkan secara keseluruhan makna teks yang bersangkutan, karena kata asap merupakan simbol kehancuran atau penyakit. Kutipan tersebut diperuntukkan untuk selruh manusia. Oleh karena itu, manusia harus bisa menjaga sikap dan aibnya semasa di dunia. Kutipan tersebut termasuk alegori karena majas alegoris juga dapat diungkapkan lewat metafora yang membandingkan sesuatu, dapat berupa karakter, semangat, aktivitas, bahkan juga tokoh, dengan cerita lain yang dikembangkan sebagai pembanding. Akan tetapi, membandingkan secara keseluruhan makna teks yang bersangkutan.

Kutipan 9

Dengan tetangga berbuat baik

Bagaikan orang adik beradik

Janganlah suka usik mengusik

Hidup sentosa sehilir semudik

Kutipan 9 larik 2 tunjuk ajar Melayu tersebut termasuk majas simile karena mempergunakan kata-kata perbandingan langsung atau eksplisit untuk membandingkan sesuatu yang dibandingkan dengan pembandingnya. Kata perbandingan langsung tersebut terdapat pada larik 4 bagaikan orang adik beradik yaitu penggunaan kata bagaikan.

Analisis Stilistika dalam Tunjuk Ajar Melayu karya Tenas Effendy 
2. Majas Pertautan dalam Tunjuk Ajar Melayu Karya Tenas Effendy

Kutipan 1

Wahai segala orang Melayu

Di dalam Islam hidup matimu

Kepada Allah segala sembah

Memuja muji sepanjang waktu

Kutipan 1 larik 1 dan 2 tunjuk ajar Melayu tersebut termasuk majas sinekdoki kategori totum pro parte karena pernyataan yang menyebutkan sesuatu secara keseluruhan, namun sebenarnya itu sebagian dari sesuatu tersebut. Majas tersebut terdapat pada larik 1 dan 2 yaitu wahai segala orang Melayu, di dalam Islam hidup matimu. Larik 1 wahai segala orang Melayu mewakili seluruh orang yang bersuku Melayu. Sementara itu, larik $2 d i$ dalam Islam hidup matimu merupakan sebagian yang dimaksudkan karena tidak semua yang bersuku Melayu beragama Islam.

\section{Kutipan 2}

Kita bertaqwa kepada Allah

Memohon ampun mengharap rahmah

Supaya hidup beroleh faedah

Sesuda mati mendapat berkah

Kutipan 2 larik 1, 2, 3, 4 tunjuk ajar Melayu tersebut termasuk majas sinekdoki kategori totum pro parte karena pernyataan yang menyebutkan sesuatu secara keseluruhan, namun sebenarnya itu sebagian dari sesuatu tersebut. Majas tersebut terdapat pada larik 1,2,3, dan 4 yaitu kita bertaqwa kepada Allah, memohon ampun mengharap rahmah, supaya hiduo beroelh faedah, sesudah mati mendapat berkah. Larik tersebut mewakili seluruh manusia atau orang bertakwa kepada Allah Swt akan mendapatkan rahmah, faedah, dan keberkahan. Akan tetapi, tidak semua kita yaitu manusia termasuk kepada orang-orang yang bertakwa.

Kutipan 3

Wahai segala kaum kerabat Elokkan perangai luruskan niat Kepada Allah banyak bertobat Supaya selamat dunia akhirat
Kutipan 3 larik 1, 2, 3, dan 4 tunjuk ajar Melayu tersebut termasuk majas sinekdoki kategori totum pro parte karena pernyataan yang menyebutkan sesuatu secara keseluruhan, namun sebenarnya itu sebagian dari sesuatu tersebut. Larik 1 wahai segala orang kaum kerabat mewakili seluruh saudara, memiliki pertalian keluargaan, dan sebagainya. Sementara itu, larik 2, 3, dan 4 elokkan perangai lurukan niat, kepada Allah banyak bertobat, supaya selamat dunia akhirat merupakan sebagian yang dimaksudkan karena tidak semua kerabat atau saudara memiliki perangai dan niat yang baik, bertaubat, dan selamat dunia akhirat.

\section{Kutipan 4}

Wahai segala anak dan cucu

Kepada Allah tempat bertumpu

Kepada-Nya tempat kita mrngadu

Supaya selamat hidup matimu

Kutipan 3 larik 1,2, 3, dan 4 tunjuk ajar Melayu tersebut termasuk majas sinekdoki kategori totum pro parte karena pernyataan yang menyebutkan sesuatu secara keseluruhan, namun sebenarnya itu sebagian dari sesuatu tersebut. Larik 1 wahai segala anak dan cucu mewakili seluruh anak dan cucu. Sementara itu, larik 2, 3, dan 4 kepada Allah tempat bertumpu, kepada-Nya tempat kita mengadu, supaya selamat hidup matimu merupakan sebagian yang dimaksudkan karena tidak semua anak dan cucu bertumpu kepada Allah, mengadu dan selamat di dunia maupun akhirat kelak.

Kutipan 5

Inilah nasihat ibu dan bapa

Untuk ananda putera tercinta

Simaklah dengan hati terbuka

Semoga Allah merahmati kita

Kutipan 6

Wahai ananda permata ibu

Kepada Allah kita bertumpu

Semoga iman melekat dalam kalbu

Di jalan yang lurus kita menuju

Kutipan 7

Wahai ananda buah hati ayah

Analisis Stilistika dalam Tunjuk Ajar Melayu karya Tenas Effendy 
Banyaklah sujud meyembah Allah

Mohon ampu beserta hidayah

Hidup dan matimu iman tak goyah

Kutipan 8

Wahai ananda cahaya mata

Peganglah pesan ibu dan bapa

Kepada Allah tempat meminta

Supaya hidupmu tidak bernista

Kutipan 9

Wahai ananda dengarlah pesan

Ibu dan bapa wajib dimuliakan

Jasanya besar bukan buatan

Dunia akhirat tiada terlupakan

Kutipan 10

wahai ananda dengarlah amanat

Ke ibu bapa hendaklah hormat

Budi mereka hendaklah ingat

Supaya selamat dunia akhirat

Kutipan 5, 6, 7, 8, 9, dan 10 tunjuk ajar Melayu tersebut termasuk majas sinekdoki kategori totum pro parte karena pernyataan yang menyebutkan sesuatu secara keseluruhan, namun sebenarnya itu sebagian dari sesuatu tersebut. Larik 2 pada kutipan 5, larik 1 pada kutipan 6, 7, 8, 9, dan 10 mewakili seluruh anak di atas dunia ini. Sementara itu, Larik 3, dan 4 pada kutipan 5, larik 2, 3, dan 4 pada kutipan 6, 7, 8, 9, dan 10 merupakan sebagian yang dimaksudkan karena tidak semua anak akan taat kepada Allah, taat kepada orang tua, dan selamat di dunia maupun akhirat kelak.

Kutipan 11

Sudah menjadi adat melayu

Pemimpin menjadi puncak teraju

Memayungi umat hilir dan hulu

Mendamaikan umat menjauhi seteru

Kutipan 12

Sudah menjadi sifat melayu

Mentaati pemimpin sejak dahulu

Sanggah menyanggah mereka malu

Apatah lagi seteru berseteru

Kutipan 11 dan 12 larik 1,2, 3, dan 4 tunjuk ajar Melayu tersebut termasuk majas sinekdoki kategori totum pro parte karena pernyataan yang menyebutkan sesuatu secara keseluruhan, namun sebenarnya itu sebagian dari sesuatu tersebut. Majas tersebut terdapat pada larik 1 mewakili seluruh orang yang bersuku, beradat, dan bersifat Melayu. Sementara itu, larik 2, 3, dan 4 merupakan sebagian yang dimaksudkan karena tidak semua yang bersuku, beradat, dan bersifat Melayu mempunyai sifat yang baik, taat kepada pemimpin, dan tidak suka beseteru satu sama lain.

Kutipan 13

Pemimpin amanah kita taati

Pemimpin yang adil kita patuhi

Arif dan bijaknya kita hormati

Budi bahasanya kita teladani

Kutipan 14

Pemimpin yang adil kita muliakan

Suruh dan tegahnya kita ikutkan

Supaya hidup terasa nyaman

Rakyat sentosa negeripun aman

Kutipan 15

Terhadap pemimpin elok perangai

Janganlah pula dibawa bertelikai

Nasehatnya diingat serta dipakai

Kutipan 16

Supaya negeri rukun dan damai

Karenanya jangan lupa petuah

Raja adil raja disembah

Raja zalim raja disanggah

Supaya hidup beroleh berkah

Kutipan 13, 14, 15, dan 16 tunjuk ajar Melayu tersebut termasuk majas sinekdoki kategori totum pro parte karena pernyataan yang menyebutkan sesuatu secara keseluruhan, namun sebenarnya itu sebagian dari sesuatu tersebut. Kutipan 13, 14, 15, dan 16 mewakili seluruh pemimpin, raja, kepala keluarga, atasan dan sejenis. Sementara itu, sebagian yang dimaksudkan karena tidak semua pemimpin, raja, kepala keluarga, atasan yang harus ditaati, disembah, dan dipuja karena adil, amanah, dan elok tingkah lakunya.

Kutipan 17

Wahai segala adik dan abang

Ariflah mendengar petuah orang

Yang elok dipakai yang buruk dibuang

Jadi bekalan di masa mendatang

Kutipan 17 larik 1,2, 3, dan 4 tunjuk ajar Melayu tersebut termasuk majas sinekdoki kategori totum pro parte karena pernyataan

Analisis Stilistika dalam Tunjuk Ajar Melayu karya Tenas Effendy 
yang menyebutkan sesuatu secara keseluruhan, namun sebenarnya itu sebagian dari sesuatu tersebut. Larik 1 wahai segala adik dan abang mewakili seluruh adik, abang dan sebagainya. Sementara itu, larik 2, 3, dan 4 ariflah mendengar petuah orang, yang elok dipakai yang buruk dibuang, jadi bekalan di masa mendatang merupakan sebagian yang dimaksudkan karena tidak semua adik, abang dan sebagainya menjadi orang-orang yang arif dan bijaksana di dalam beperilaku.

\section{Kutipan 18}

Karena itu wahai sahabat

Jagalah jangan patah semagat

Patah semagat hidup melarat

Sebarang tujuan tak pernah dapat

Kutipan 19

Wahai segala handai dan tolan

Bertanam budi kita utamakan

Berbuat kebaikan jadi amalan

Supaya hidup beroleh keberkahan

Kutipan 20

Karena itu wahai sahabat

Hidup jangan meninggalkan adat

Junjuglah dengan sepenuh minat

Supaya sejahtera dunia akhirat

Kutipan 18, 19, dan 20 larik 1, 2, 3, dan 4 tunjuk ajar Melayu tersebut termasuk majas sinekdoki kategori totum pro parte karena pernyataan yang menyebutkan sesuatu secara keseluruhan, namun sebenarnya itu sebagian dari sesuatu tersebut. Kutipan 18, 19, dan 20 mewakili seluruh sahabat, kawankawan, teman-teman dan sejenis. Sementara itu, sebagian yang dimaksudkan karena tidak semua sahabat, kawan-kawan, teman-teman yang memiliki semangat yang tinggi, berbaik budi, dan sejahtera dunia dan akhirat.

\section{SIMPULAN}

Berdasarkan hasil dan pembahasan analisis stilistika dalam tunjuk ajar Melayu karya Tenas Effendy dapat disimpulkan sebagai berikut:

1. Majas perbandingan dalam tunjuk ajar Melayu karya Tenas Effendy terdiri atas, majas simile, personifikasi, metafora, dan alegori.
2. Majas pertautan dalam tunjuk ajar Melayu karya Tenas Effendy terdiri atas, majas sinekdoki kategori tutum pro parte.

\section{REFERENSI}

Alber. (2017). Tunjuk Ajar Melayu dalam Syair Tenas Effendy sebagai Basis Pendidikan Karakter. GERAM, 5(2), 3643. Retrieved from http://journal.uir.ac.id/index.php/geram/a rticle/view/665/657

Andriani, T. (2015). Revitalisasi Naskah Syair: Sebuah Solusi Dalam Pengembangan Kreativitas Mahasiswa Untuk Mencintai Budaya Lokal. Jurnal Pendidikan Bahasa Dan Sastra, 15(1), 26-35. https://doi.org/10.17509/bs_jpbsp.v15i1. 796

Ardin. Anita Safitri dkk. (2020). Perahu Kertas Karya Sapardi Djoko Damono ( Kajian Stilistika ). 5(4), 50-59.

Assadiyah, H. dkk. (2018). Analisis Kesalahan Berbahasa Bidang Sintaksis dalam Teks Biografi Siswa Kelas X SMA Negeri 7 Padang. Deiksis: Jurnal Pendidikan Bahasa Dan Sastra Indonesia, 5(2), 16. https://doi.org/10.33603/deiksis.v5i2.119 7

Azizah, A. dan L. N. S. (2019). Kajian Stilistika Buku Antologi Puisi dan aplikasi Pembelajaran di Perguruaan Tinggi. 7(1), 1-10.

Effendy, T. (2013). Tunjuk Ajar Melayu dalam Pantun, Gurindam, Seloka, Syair, dan Ungkapan. Provinsi Riau: Tenas Effendy Foundation.

Fatmalinda, L. dkk. (2016). Stilistika Dalam Novel Ayah Karya Andrea Hirata. Jurnal Pendidikan - Teori, Penelitian, Dan Pengembangan, 1(5), 993-995. https://doi.org/10.17977/jp.v1i6.6352

Fransori, A. (2017). Analisis Stilistika Pada Puisi Kepada Peminta-Minta Karya Chairil Anwar. Deiksis, 09(01), 1-12.

Keraf, G. (2010). Diksi dan Gaya bahasa. Jakarta: Gramedia Pustaka Utama.

Munir, S. dkk. (2013). Diksi dan Majas dalam Kumpulan Puisi Nyanyian dalam Kelam Karya Sutikno W.S: Kajian Stilistika. Jurnal Sastra Indonesia, 2(1), 1-10.

Analisis Stilistika dalam Tunjuk Ajar Melayu karya Tenas Effendy 
Retrieved

from

https://journal.unnes.ac.id/sju/index.php/j si/article/view/2437

Nurgiyantoro, B. (2014). Stilistika. Yogyakarta: Gadjah Mada Universcity Press.

Ratna, N. K. (2009). Stilistika:Kajian Puitika Bahasa Sastra dan Budaya. Yogyakarta: Pustaka Pelajar.

Rosmini dkk. (2017). Diksi dan Gaya Bahasa Syair Lagu Karya Didi Kempot. Bahasantodea, 5(2), 92-101.

Wirasari, I. dan T. E. B. K. (2018). Kajian Gaya Bahasa Iklan Antangin Fit Pada Media Sosial. Demandia, 3(02), 1-15. https://doi.org/10.25124/demandia.v3i02. 1545 